\title{
CONSERVATION OF THE FLOWERS CANVAS PAINTING (1) AT THE EGYPTIAN AGRICULTURAL MUSEUM
}

\author{
Elsayed, Y. \\ Conservation dept., Faculty of Archaeology, Damietta Univ., Damietta, Egypt \\ E-mail: yea00@fayoum.edu.eg
}

\begin{abstract}
The present study aims to examine and treat the flowers canvas painting at the Egyptian Agricultural Museum. It is divided into three parts: a) USBDM, SEM-EDX, XRD, GC and FTIR studies, which revealed that the object is suffering from deterioration forms, e.g. ruptures, dust, cracks, missing parts, brittleness, fragility, acidified canvas, and incompatible treatments. The coloring materials are: The green is celadonite $\left(\mathrm{K}\left(\mathrm{Ca}, \mathrm{Mg}, \mathrm{Fe}_{2}\right)\left(\mathrm{Fe}_{3} \mathrm{Al}\right)\left[\mathrm{Si}_{4} \mathrm{O}_{10}\right](\mathrm{OH})_{2}\right)$, the red is hematite $\left(\mathrm{Fe}_{2} \mathrm{O}_{3}\right)$, the blue is lazurite $\left.(\mathrm{Na}, \mathrm{Ca})_{8}\left(\mathrm{AlSiO}_{4}\right)_{6}\left(\mathrm{SO}_{4}, \mathrm{~S}, \mathrm{Cl}\right)_{2}\right)$, the beige is hematite $\left(\mathrm{Fe}_{2} \mathrm{O}_{3}\right)$ mixed with barite (BaSO4) and zincite ( $\mathrm{ZnO})$, and the gray is carbon black (C). Additionally the ground layer consists of hydrocerussite $\mathrm{PbCO}_{3} \cdot(\mathrm{OH})_{2}$, cerussite $\mathrm{Pb}_{3} \mathrm{CO}_{3}$ and zincite $\mathrm{ZnO}$ binded with animal glue. The oil media is the poppy seed oil. b) The experimental part showed that $7 \%$ Beva371 in toluene is more suitable than the fish glue for object consolidation. c) The applied part covered cleaning, consolidation, patching, lining, completing the missing parts in the painting and ground layers and varnishing.
\end{abstract}

Keywords: Canvas painting, Binding media, Investigation, Conservation, Lining, Inpainting.

\section{Introduction}

Canvas paintings comprise many organic and inorganic components. Canvas is made of natural fibers such as linen, hemp and cotton. It is the most sensitive and susceptible component in the painted object $[1,2]$. These different components usually result in heterogeneous reactions by the deterioration factors. When canvas absorbs humidity, it swells, when loss it, it shrinks. These alternative processes lead to creat paint cracks. Then canvas gradually losses its strength and elasticity over time. Accordingly, it fails to play its role as a supporting substrate for the painting and ground layers [3-5]. Due to the exposure to deterioration factors, the painting components usually undergo different changes, e.g. physical changes caused by fluctuations in temperature and humidity and chemical changes due to oxidation promoted by humidity, light, and environmental pollutants $[6,7]$. Moreover, the oils in the painting and ground layers can cause much deterioration phenomena (e.g. brittleness, color changes, loss of tearing resistance, curling of the painting and decrease of the degree of polymerization) by increasing the aging period. The high humidity can cause the canvas to be attacked by microorganisms, leading to more bio-deterioration features that affect the fibers $[6,8,9]$. Therefore, the optimum preservation of the deteriorated cultural heritage requires detailed information about the object, including the components, history, techniques and different processes to which the object had been exposed. While some investigation and analysis methods are greatly beneficial in providing sufficient data from the macro-samples, 
others are non-destructive and more beneficial [10-12]. Many articles have elaborated the different techniques for the investigation and analysis of paintings, e.g. SEM with EDX and X-Ray Spectroscopy Raman Spectroscopy, FTIR, Ion Chromatography, Mass Spectroscopy, etc. They are all considered the most common techniques used for identifying not only organic and inorganic components, but also the deterioration features and treatment and preservation strategies to be adopted, as well [13-15]. The present study examines the case of the flowers painting (1), fig. (1-a,b), by the Egyptian painter Ali Kamel Eldeeb ${ }^{(\mathrm{a})}$ in the heritage collections building at the Egyptian Agricultural Museum, which contains many paintings of great painters, such as Amelia Casonato, John Ralef, Hedyat Shirazi, Mahmoud Sa'id, Hosni Alb-anani, Ali Alahwani, Ali Kamel Eldeeb, etc. It also holds other rare collections (glassware, metal artifacts, wood, manuscripts, books, portraits, carpets, textiles, etc.) dated back to the early Coptic and Islamic eras and were owned by the former Egyptian Royal family of Mohamed Ali Pasha (ca. 1805-1952). Our case study is one of two canvas paintings entitled The Flowers Painting. It is displayed among twenty three canvas paintings collection of Ali Eldeeb on the $2^{\text {nd }}$ floor of the Heritage Collections Building at the EAM. It measure $72.5 \times$ $72.5 \mathrm{~cm}$. The painted scene shows flowers in a vase. While, the flowers are in light and dark red and green, the vase is in blue and gray shadows on a beige background. The canvas is pinned on a wooden stretcher, framed by a brown wooden one and signed by the Egyptian

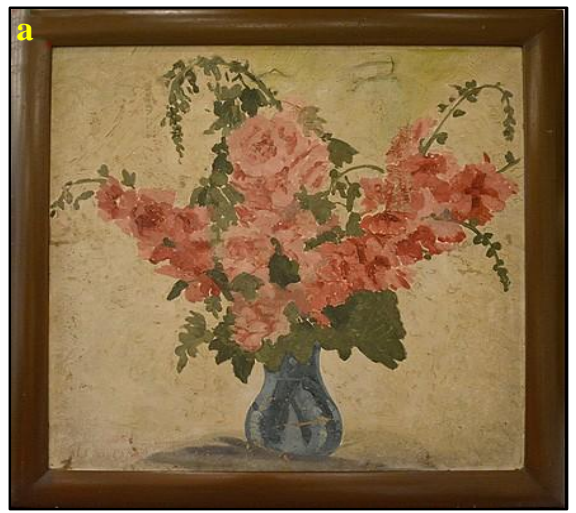

painter Ali Eldeeb, no date was included, but it had been historically and artistically dated between 1937 and 1941 based on the historical background, the artistic study and a comparison with the other twenty three paintings by the same painter. The main problem in our case was caused by the low durability in both the paint layer and twill. The paint layer is unvarnished, very thin and weak. It is characterized by low resistance to most solvents even water like all modern oil paintings in the $20^{\text {th }}$ century as attested by Lee, et al. [16], Bay, et al. [17]. The visual and macroscopic observations proved that the object extremely suffer from many deterioration forms, e.g. dust, stains, cracks, holes, macro-cracks, ruptures, missing parts in both the painting and ground layers, in addition to incorrect ancient inpaintings. Regarding the twill (canvas); it is very thin, fragile, brittle, acidified and wrongly lined by some textile and plastic patches as shown in fig. (1-c,d,e,f,g,h,i,j). Scientifically, the conservation processes of these objects need to be more accurate and careful, especially regarding any activities such as handling, cleaning, consolidation, displaying, packing etc., due to their sensitivity [18]. So, some consolidants were continuously examined to achieve this target. In this regard, Beva371 is considered the most effective copolymer used in the lining and consolidation of all flexible artifacts, such as canvas painting, paper, textiles, leather, etc. [19$21]$. The present study deeply investigates the miserable state of the flowers canvas painting which had been selected to be ideally treated for future preservation.

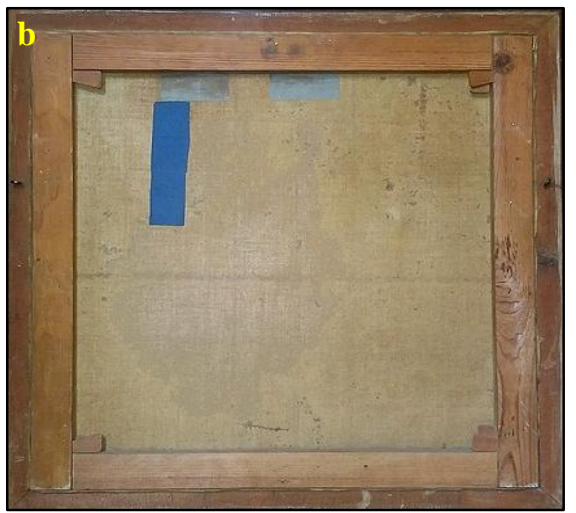



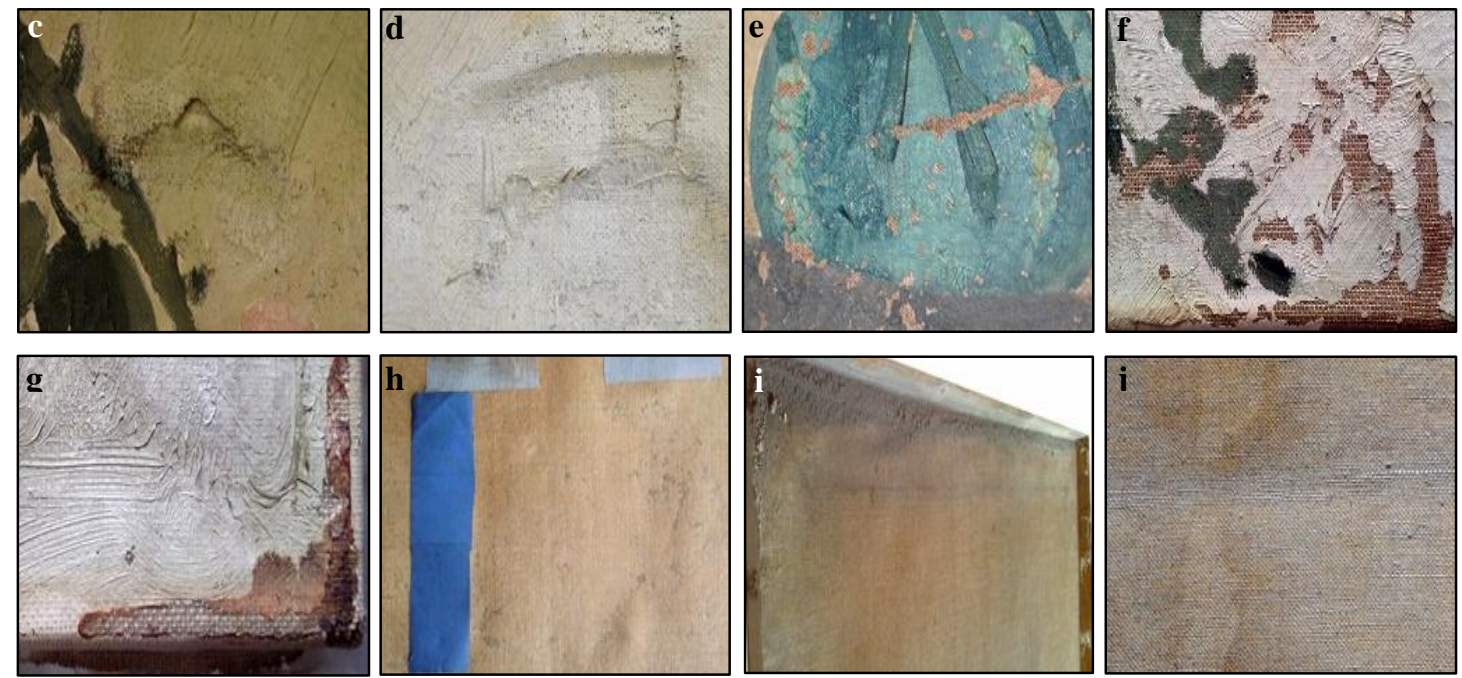

Figure (1) Shows the flowers painting (1) $\underline{\mathbf{a}}$. front, $\underline{\mathbf{b}}$. verso, in addition to some deterioration features $\underline{\mathbf{c}}$.

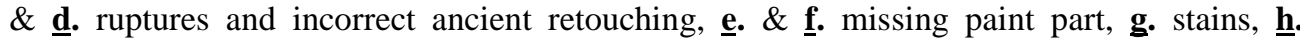
incorrect ancient patches, i. dust, $\mathbf{j}$. stained canvas

\section{Materials and Methods}

\subsection{Samples}

Six macro-samples (green, red, blue, beige, gray colors, and white ground layer) were carefully collected from different

\subsection{Investigation and analyses methods}

The samples were carefully examined and analyzed using a digital microscope connected to a PC (USBDM) with magnification (up to 200-x) to get in-situ colored images with fair magnification. In addition, Scanning Electron Microscopy SEM; Quanta 250 FEG, with the Energy-Dispersing X-ray Spectroscopy EDX unit was adopted to investigate the morphological features of the different components of the canvas. XRD (X-Ray powder diffraction; using a Philips Analytical X-Ray, PW 1840 diffractometer,

\section{Results}

\subsection{Microscopic examination}

USBDM examinations illustrated that the canvas was highly deteriorated and had cracks, macro-cracks, cleavage and fragility of both painting and ground layers. No varnish layers were detected upon the paint surface and the canvas was very brittle and weak, fig. (2-a,b,c,d). SEM examination of the canvas samples, fig. (2-e,f) clarified that the morphological features of the object fibers is linen areas in some brittle paint and ground layer in the object.
Netherland, with a $\mathrm{Cu}$ tube, $\mathrm{kv} 40$ ) was used to identify the chemical compounds of pigments and ground layers. Fourier Transform Infrared Spectroscopy (FTIR, Jasco 4100, Japan, spectral range from $4000 \mathrm{~cm}^{-1}$ to $500 \mathrm{~cm}^{-1}$, and a resolution of $5 \mathrm{~cm}^{-1}$ ) was used, to identify the glue type. Finally, a Gas Chromatograph (Agilent Inc., 6890 series, USA, equipped with a DB23 $60 \mathrm{~m} \times 0.32 \mathrm{~mm} \times 0.25 \mu \mathrm{m}$ capillary column had been used after separation according to the standard methods [22, 23] for to identify the drying oil

type compared to the standards morphology of the fiber's type as argued by Needles [24]. Moreover, it revealed the brittleness and weakness of these fibers. Regarding the paint and the ground layers, the results revealed the extreme destructive condition of the object, including cracks, macro-cracks and fragility, as shown in fig. (2-g,h). 

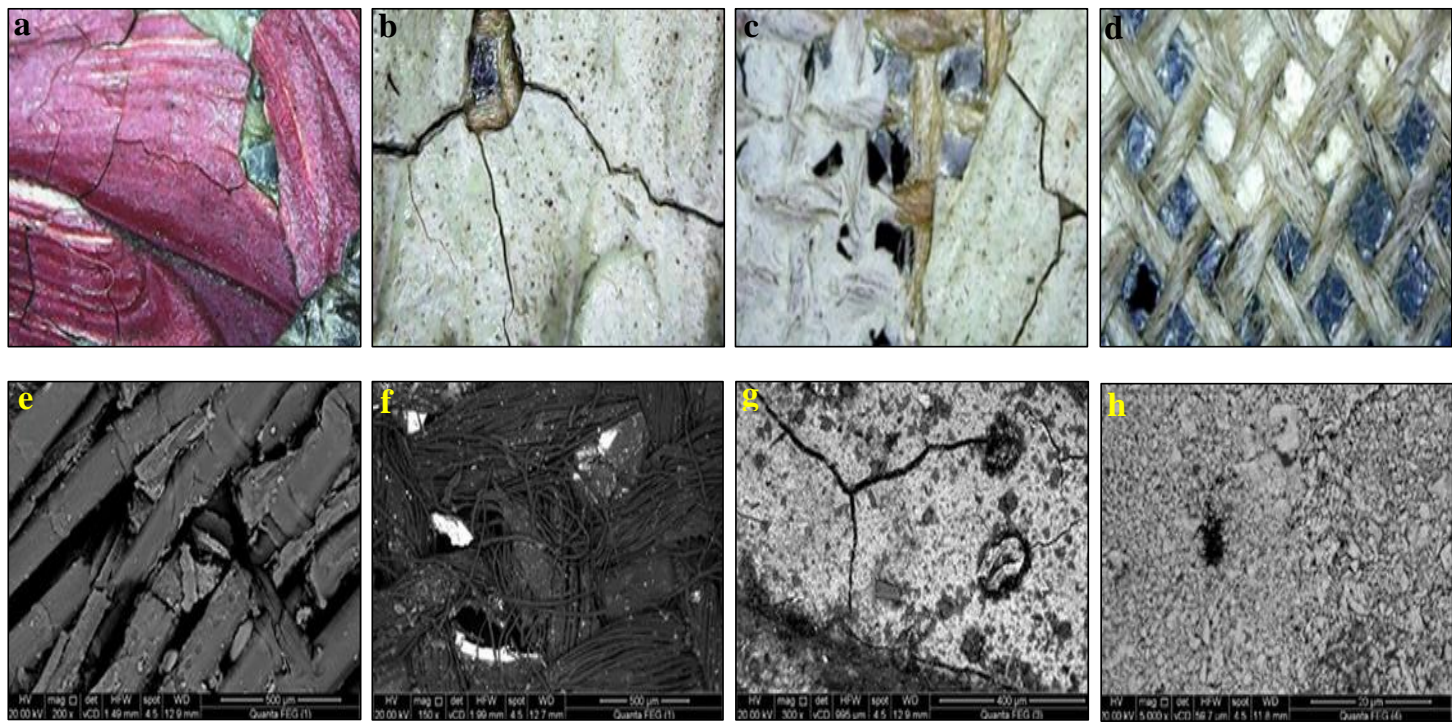

Figure (2) Shows some deterioration features in the flowers painting (1) USBDM examination, $\underline{\mathbf{a}}$. \& $\underline{\mathbf{b}}$. cracks, macro-cracks and fragility of the painting layer, $\underline{\mathbf{c}}$. \& $\underline{\mathbf{d}}$. brittle, stained canvas, and SEM examination, $\underline{\mathbf{e}}$. \& $\underline{\mathbf{f}}$. brittleness of linen canvas, g. \& $\underline{\mathbf{h}}$. cracks, macro-cracks and fragility of ground and painting layers

\subsection{Analytical results of the pigments and ground layers}

XRD results, table (1) suggested that the main mineralogical components of the pigments were celadonite and barite for the green color. Barite, hematite, cerussite and hydrocerussite were the components of red color, while ultramarine, cerussite and zincite for blue color. Barite, zincite and hematite were used for the beige color and earth green, eskolite, barite and zincite were the main minerals used for producing the gray color. Finally, hydrocerussite, cerussite and zincite were the main minerals for the ground layer, fig. (3-a,b,c,d,e,f). These results match the EDX results reportyed by Elsayed [25].

Table (1) Data of XRD analytical results of the six pigmented samples and ground layer used in the flowers painting (1)

\begin{tabular}{|c|c|c|}
\hline Sample & Components & $\%$ \\
\hline \multirow{2}{*}{ Green } & Celadonite $\left.\mathrm{K}\left(\mathrm{Ca}, \mathrm{Mg}, \mathrm{Fe}_{2}\right)\left(\mathrm{Fe}_{3} \mathrm{Al}\right)\left[\mathrm{Si}_{4} \mathrm{O}_{10}\right](\mathrm{OH})_{2}\right)$ & 79.3 \\
\hline & Barite $\mathrm{BaSO}_{4}$ & 20.7 \\
\hline \multirow{4}{*}{ Red } & Barite $\mathrm{BaSO}_{4}$ & 70.1 \\
\hline & Hematite $\mathrm{Fe}_{2} \mathrm{O}_{3}$ & 25.3 \\
\hline & Hydrocerussite $\mathrm{PbCO}_{3 \cdot} \cdot(\mathrm{OH})_{2}$ & 3.2 \\
\hline & Cerussite $\mathrm{Pb}_{3} \mathrm{CO}_{3}$ & 1.8 \\
\hline \multirow{3}{*}{ Blue } & Ultramarine Blue (Lazurite) $\left.(\mathrm{Na}, \mathrm{Ca})_{8}\left(\mathrm{AlSiO}_{4}\right)_{6}\left(\mathrm{SO}_{4}, \mathrm{~S}, \mathrm{Cl}\right)_{2}\right)$ & 82.9 \\
\hline & Cerussite $\mathrm{Pb}_{3} \mathrm{CO}_{3}$ & 14.2 \\
\hline & Zincite $\mathrm{ZnO}$ & 2.9 \\
\hline \multirow{3}{*}{ Beige } & Barite $\mathrm{BaSO}_{4}$ & 89.3 \\
\hline & Zincite $\mathrm{ZnO}$ & 7.4 \\
\hline & Hematite $\mathrm{Fe}_{2} \mathrm{O}_{3}$ & 3.3 \\
\hline \multirow{4}{*}{ Gray } & Earth Green $\left.\mathrm{K}\left(\mathrm{Ca}, \mathrm{Mg}, \mathrm{Fe}_{2}\right)\left(\mathrm{Fe}_{3} \mathrm{Al}\right)\left[\mathrm{Si}_{4} \mathrm{O}_{10}\right](\mathrm{OH})_{2}\right)$ & 58.9 \\
\hline & Eskolite $\mathrm{CR}_{2} \mathrm{O}_{3}$ & 18.7 \\
\hline & Barite $\mathrm{BaSO}_{4}$ & 16.5 \\
\hline & Zincite $\mathrm{ZnO}$ & 5.9 \\
\hline \multirow{3}{*}{ Ground layer } & Hydrocerussite $\mathrm{PbCO}_{3} \cdot(\mathrm{OH})_{2}$ & 89.7 \\
\hline & Cerussite $\mathrm{Pb}_{3} \mathrm{CO}_{3}$ & 9.2 \\
\hline & Zincite $\mathrm{ZnO}$ & 1.1 \\
\hline
\end{tabular}



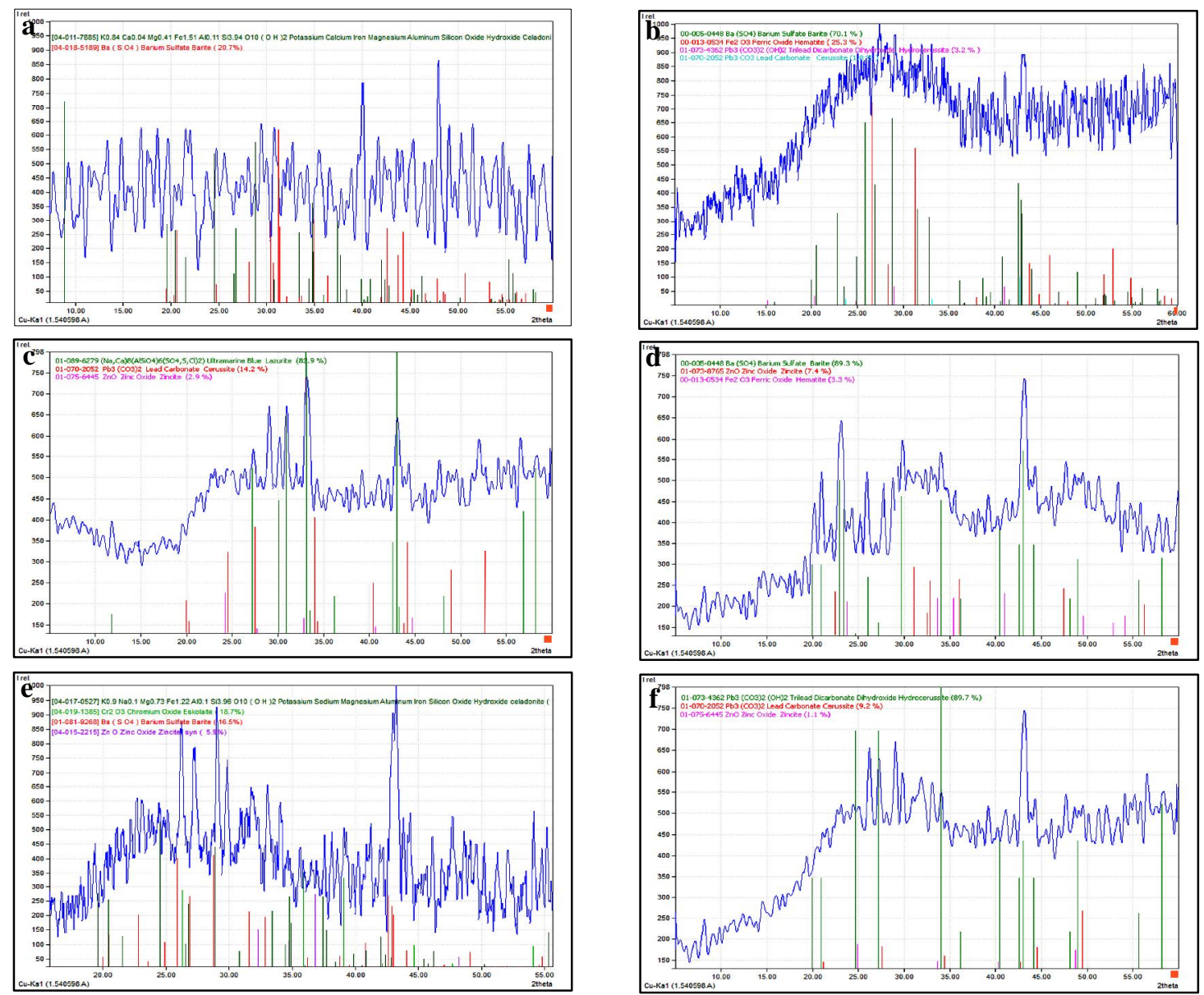

Figure (3) Shows XRD patterns of the six pigmented samples and ground layer used in the flowers painting (1), a. ., green, $\underline{\mathbf{b}}$. red, $\underline{\mathbf{c}}$. blue, $\underline{\mathbf{d}}$. beige, $\underline{\mathbf{e}}$. gray, $\underline{\mathbf{f}}$. ground layer

\subsection{Analytical results of binding media}

FTIR spectrum of the adhesive material of the white ground layer, fig. (4-a) revealed that the binding media is the animal glue. All types of glue had long polysaccharide chains that contain a high proportion of O-H group associated with carbon and appears at $3400 \mathrm{~cm}^{-1}$ [26,27]. Furthermore, N-H stretching bands characterize the animal glue at $3525 \mathrm{~cm}^{-1}$, and Asymmetric C-H stretch at $2919 \mathrm{~cm}^{-1}$ $[28,29]$. The animal glue is a water-sol- uble collagen and it is characterized by the appearance of a frequency amide I $\left(\mathrm{C}=\mathrm{O}\right.$ stretching at $\left.1646 \mathrm{~cm}^{-1}\right)$ and amide II $(\mathrm{C}-\mathrm{N}-\mathrm{H}$ deformation $+\mathrm{O}-\mathrm{C}-\mathrm{N}$ stretching at $1547 \mathrm{~cm}^{-1}$ ) [30], all of these data are listed in tab. (2). Furthermore, GC spectrum of the drying oil fig. (4-b) revealed that the binding oil was the poppyseed oil, which was previously identified in detail by Elsayed [25].

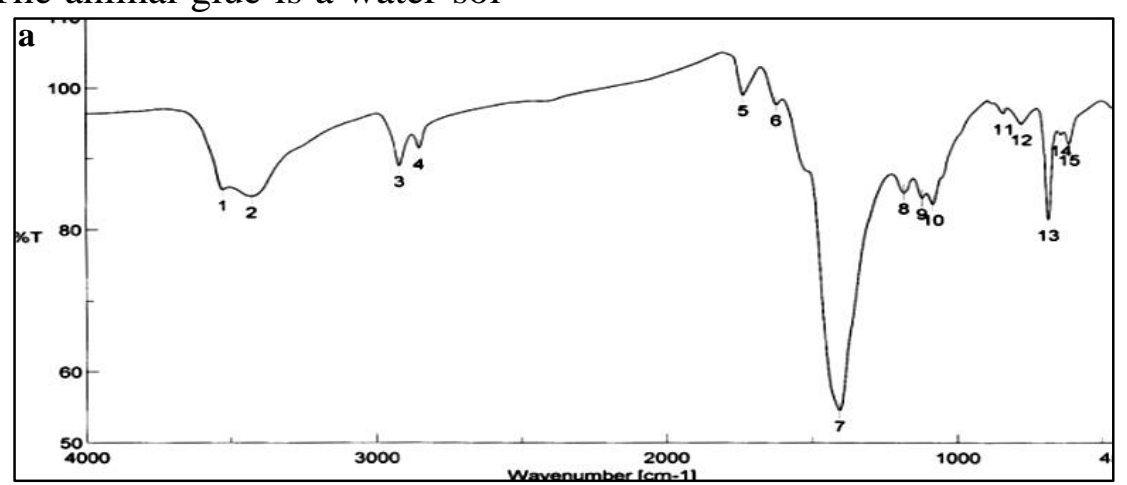

Figure (4-a) Shows FTIR spectrum of the ground layer 
Table (2) Functional groups of the ground layer spectrum

\begin{tabular}{lc}
\hline \multicolumn{1}{c}{ Functional Groups } & Wavenumbercm \\
\hline NH Stretching band & $3525 \mathrm{~cm}^{-1}$ \\
OH stretching band & $3424 \mathrm{~cm}^{-1}$ \\
Asymmetric CH stretching bands & $2919 \mathrm{~cm}^{-1}$ \\
Symmetric CH stretching bands & $2919 \mathrm{~cm}^{-1}$ \\
C = O stretching band & $1617 \mathrm{~cm}^{-1}$ \\
C - N - H bending band & $1617 \mathrm{~cm}^{-1}$ \\
CH bending bands & $1464 \mathrm{~cm}^{-1}$ \\
CO stretching bands & $1464 \mathrm{~cm}^{-1}$ \\
\hline
\end{tabular}

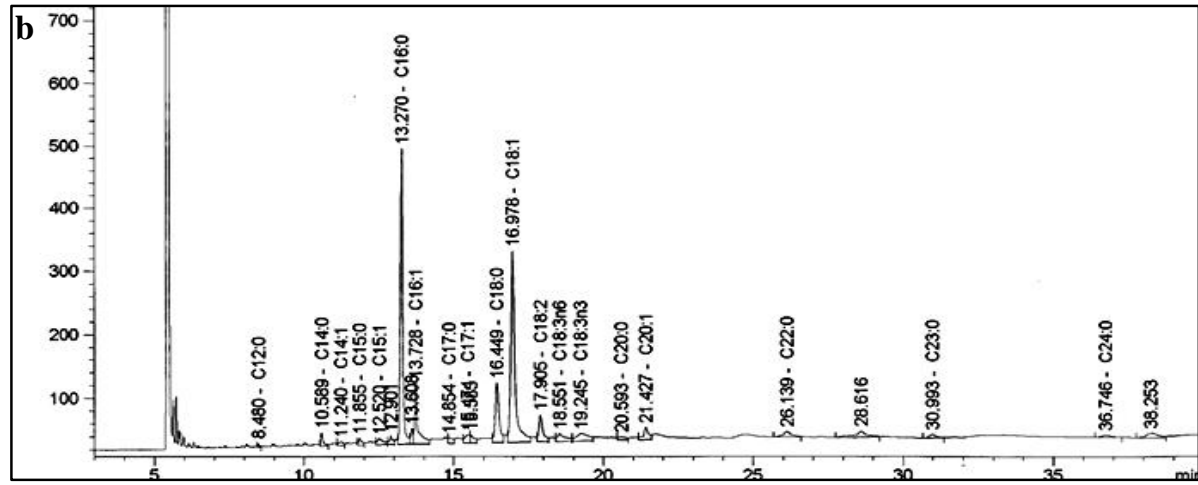

Figure (4-b) Shows GC spectrum of the drying oil

\section{Applied Study}

\subsection{Experiments}

The experiments aim at estimating the most suitable material and methods of consolidation in our case study. Although, Beva371 and fish glue are well-known as suitable consolidant materials, the study tried to test which one is more effective for realizing the application target. So, the experimental samples had been prepared according to the above examination results. Lead carbonate and zinc oxide were mixed with water and animal glue, then brushed upon a linen textile support. In this regard, three color formulas were prepared; a) the green formula (celadonite + barite $4: 1$ ), b) the red formula (hematite + barite 4:1) and c) the beige formula (barite + hematite 4:1) mixed with the poppyseed oil and brushed over the white ground layer. After drying and initial investigation, the samples were thermally aged at $105^{\circ} \mathrm{C}$ for 144 hours according to Seves, et al. [6]. The aged samples were separately consolidated by $7 \%$ Beva371 in toluene and 7\% fish glue in water, then they were re-aged in the natural weathering for two months (from the beginning of April to the end of May) to assay the efficiency and sustainability of consolidant materials in the future [4], as shown in fig. (5).

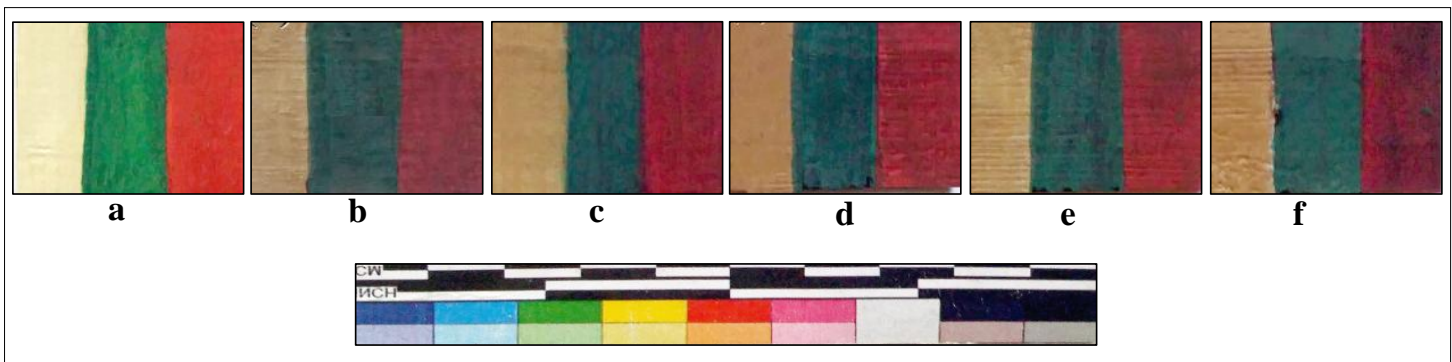

Figure (5) Shows the experimental samples, $\underline{\mathbf{a}}$. fresh sample, $\underline{\mathbf{b}}$. fresh aged sample, $\underline{\mathbf{c}}$. Beva371 consolidated sample, $\underline{\mathbf{d}}$. fish glue consolidated sample, $\underline{\mathbf{e}}$. Beva371 consolidated aged sample, $\mathbf{f}$. fish glue consolidated aged sample 
Within the same context, color meter (DR LANGE MICRO COLOR LDC20II) was adapted for evaluating the probable color changes through measuring color variation in each sample before and after treatment. The results listed in tab. (3) revealed that the average of the color changes in the samples treated with fish glue is higher than those treated with Beva371 especially in the red color area. After the ageing process, the average of the color changes also increased in all samples, especially those treated with the fish glue than those treated with Beva371, Additionally, the red color area revealed the highest color changes. These results suggest that using $7 \%$ Beva371 in toluene for the consolidation of aged canvas painting is more efficient and suitable than the same percentage of fish glue. In addition, BEVA 371 has many advantages, as a consolidating material, such as good adhesion capability in most cases, plasticity, reversibility and re-applicability, either in cold or warm way.

Table (3) Results of colorimetric measurements of the experimental samples after treatment \& aging processes

\begin{tabular}{|c|c|c|c|c|c|c|c|c|c|c|c|c|}
\hline \multirow{3}{*}{ 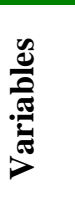 } & \multicolumn{6}{|c|}{ After treatment only } & \multicolumn{6}{|c|}{ After treatment \& aging } \\
\hline & \multicolumn{3}{|c|}{ Beva371 } & \multicolumn{3}{|c|}{ Fish glue } & \multicolumn{3}{|c|}{ Beva371 } & \multicolumn{3}{|c|}{ Fish glue } \\
\hline & $\begin{array}{l}\text { W } \\
\text { color }\end{array}$ & $\begin{array}{c}\mathrm{G} \\
\text { color }\end{array}$ & $\begin{array}{c}\mathrm{R} \\
\text { color }\end{array}$ & $\begin{array}{l}\text { W } \\
\text { color }\end{array}$ & $\begin{array}{c}\mathrm{G} \\
\text { color }\end{array}$ & $\begin{array}{c}\mathrm{R} \\
\text { color }\end{array}$ & $\begin{array}{l}\mathrm{W} \\
\text { color }\end{array}$ & $\begin{array}{c}\mathrm{G} \\
\text { color }\end{array}$ & $\begin{array}{c}\mathrm{R} \\
\text { color }\end{array}$ & $\begin{array}{c}\text { W } \\
\text { color }\end{array}$ & $\begin{array}{c}\mathrm{G} \\
\text { color }\end{array}$ & $\begin{array}{c}\mathrm{R} \\
\text { color }\end{array}$ \\
\hline$\Delta \mathbf{L} *$ & -0.24 & -0.43 & -0.22 & -0.58 & -0.86 & -0.81 & -1.03 & -0.94 & -1.25 & -1.57 & -1.73 & -2.13 \\
\hline$\Delta \mathbf{a}^{*}$ & 0.32 & -0.44 & 0.52 & 0.69 & -0.42 & 1.2 & 0.86 & -0.65 & 1.42 & 1.02 & -0.69 & 1.88 \\
\hline$\Delta \mathbf{b}^{*}$ & 0.51 & -0.23 & 0.67 & -0.31 & -0.83 & 1.54 & 0.75 & -0.76 & 1.04 & 0.65 & -1.32 & 1.49 \\
\hline$\Delta \mathbf{E}^{*}$ & 0.64 & 0.65 & 0.87 & 0.95 & 1.26 & 2.11 & 1.53 & 1.37 & 2.15 & 1.98 & 2.28 & 3.20 \\
\hline
\end{tabular}

Moreover, SEM was reused to investigate the samples after treatment and asses the efficacy of both consolidants on the canvas and paint layer. It was used to investigate the treated samples after the aging processes and evaluate the durability of the consolidants in the future, figs. (6). The results proved that Beva371 is more efficient in the consolidation processes than fish glue. Furthermore, it is more resistant against aging by time for both the painting layer and canvas, where, there were no notable changes in the properties of the samples treated with Beva371 after thermal ageing. On the contrary, the fish glue consolidated samples showed some deterioration symptoms such as cracks and fragility after the same ageing. Upon these results, Accordingly, Beva 371 is used as the consolidating material in our applied study.
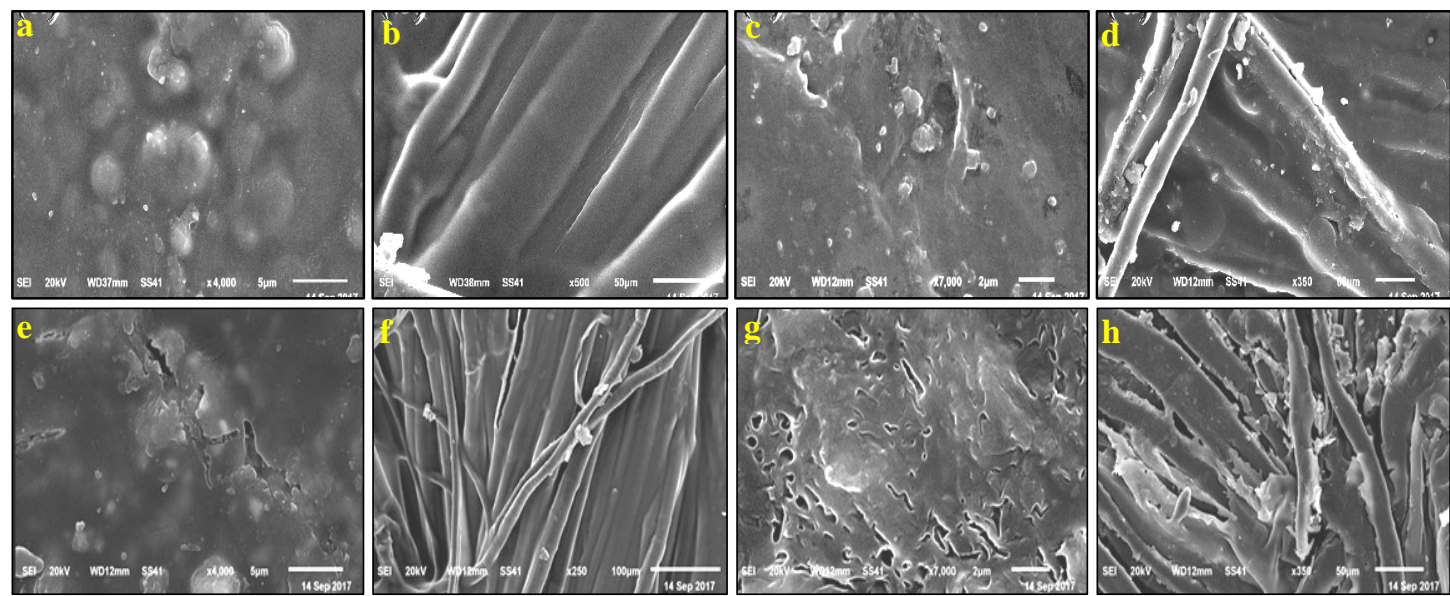

Figure (6) Shows the SEM photo micrographs of treated samples before and after aging, a. paint layer consolidated by Beva371, $\underline{\mathbf{b}}$. canvas consolidated by Beva371, $\underline{\text { c. }}$ paint layer consolidated by fish glue consolidated paint layer, $\underline{\mathbf{d}}$. canvas by consolidated fish glue, $\underline{\mathbf{e}}, \underline{\mathbf{f}}, \mathbf{g} \& \underline{\mathbf{h}}$, the same samples after ageing process 


\subsection{Treatment}

\subsubsection{Cleaning}

Different soft brushes were used to mechanically clean the dust and stains covering the painting surface, canvas and wooden frame. Then, ethyl alcohol and toluene were used for more cleaning of the hard residuals [31]. After that a gel of Triethanolamine (TEA) and citric acid

$(\mathrm{pH} 8)$ was used in cleaning of both the painting layer and the canvas, fig. (8$a, b, c)$. Finally, the ancient patches adhered to the canvas were carefully removed and the residual adhesive in the canvas were rubbed off by scalpel, then cleaned using ethyl alcohol [32,33], fig.(8-d,f).
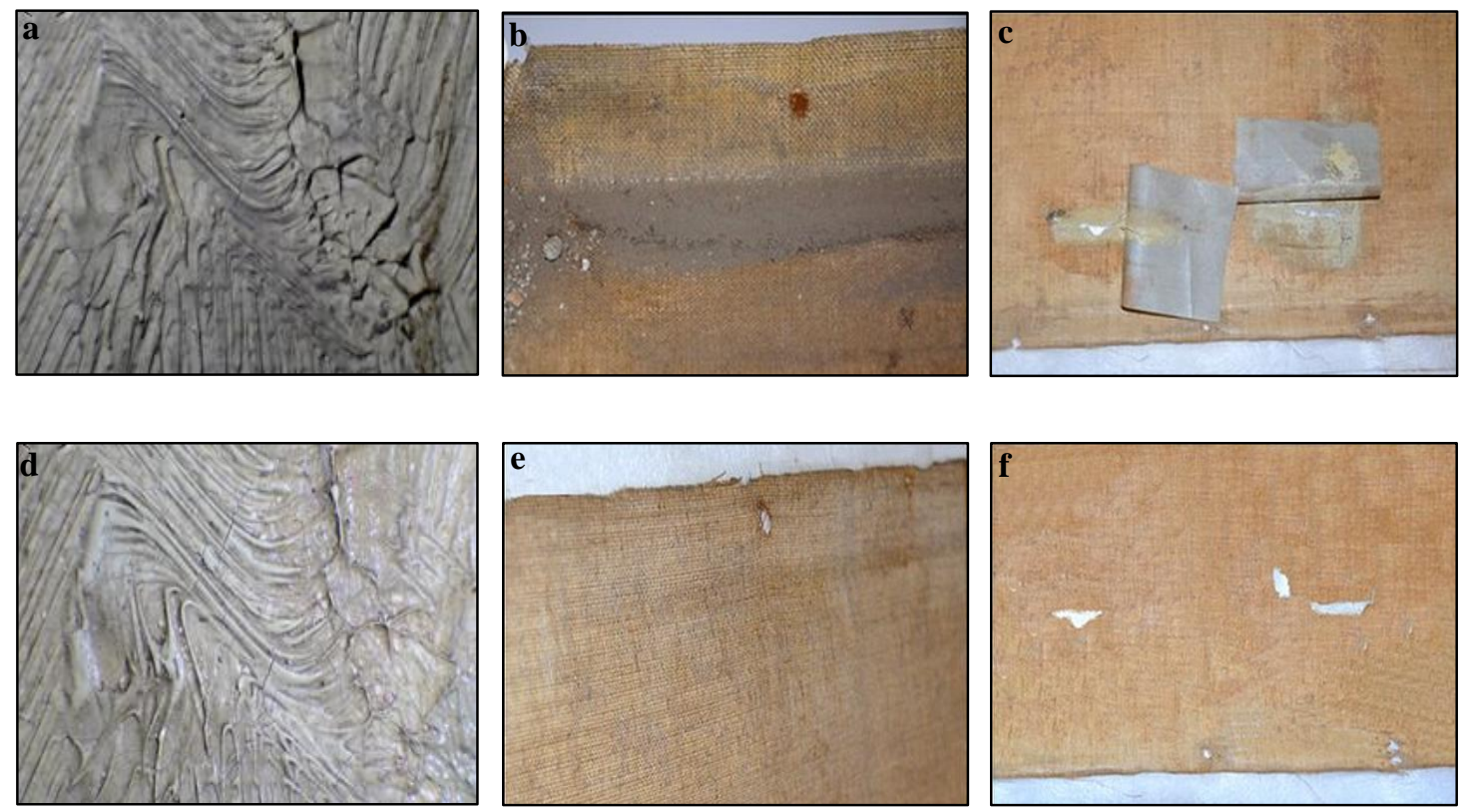

Figure (7) Shows, $\underline{\mathbf{a}}$. \& $\underline{\mathbf{b}}$., before cleaning of the object $\underline{\mathbf{c}}$., ancient fault before patches removal, $\underline{\mathbf{d}}$. \& e. the same areas in the object after cleaning, f. the same areas of ancient fault after patches removal

\subsection{Consolidation and lining}

Based on the previous experimental results and experiments of many researchers $[9,34,35]$, Beva371 was used as a consolidating material in our case study. Thus, $7 \%$ Beva371 in toluene was brushed to consolidate the painting layer, fix it and to stop falling. After that, the painting was kept to completely dry in the ambient environment as argued by Hackney [36]. In addition, both the canvas and painting layer were reinforced using 25-30\% Beva371 in toluene, which is known by lining process as attested by Stoner \& Rushfield [9] and Cruz \& Rego [32] in similar cases. This process is implemented according to Knut [4] Colta [37] as follows: a) Covering the panting surface by the Japanese tissue, using $7 \%$ Beva371 in toluene, then letting it to dry.

b) Inverting the object, (the pai-nting layer is down and the canvas is up) to fix small inserted pieces in the gaps with $30 \%$ Beva371 in toluene, coating the new linen textile support by $30 \%$ Beva371 in toluene and letting it to dry. c) Coating the new linen textile support by $30 \%$ Beva371 in toluene and keeping it dry. d) Heat-sealing of the new support using home iron at $50-60^{\circ} \mathrm{C}$, e) Pressing the object after lining under a glass plate for 24 hours to ensure the complete adhesion and stability of the painting. f) Stretching the lined painting on the wooden stretcher to prevent future moisture and bio-deterioration effects. g) Removing the Japanese tissue using toluene and cleaning the residues of excess Beva371, fig. (8-a,b,c,d,e,f). 

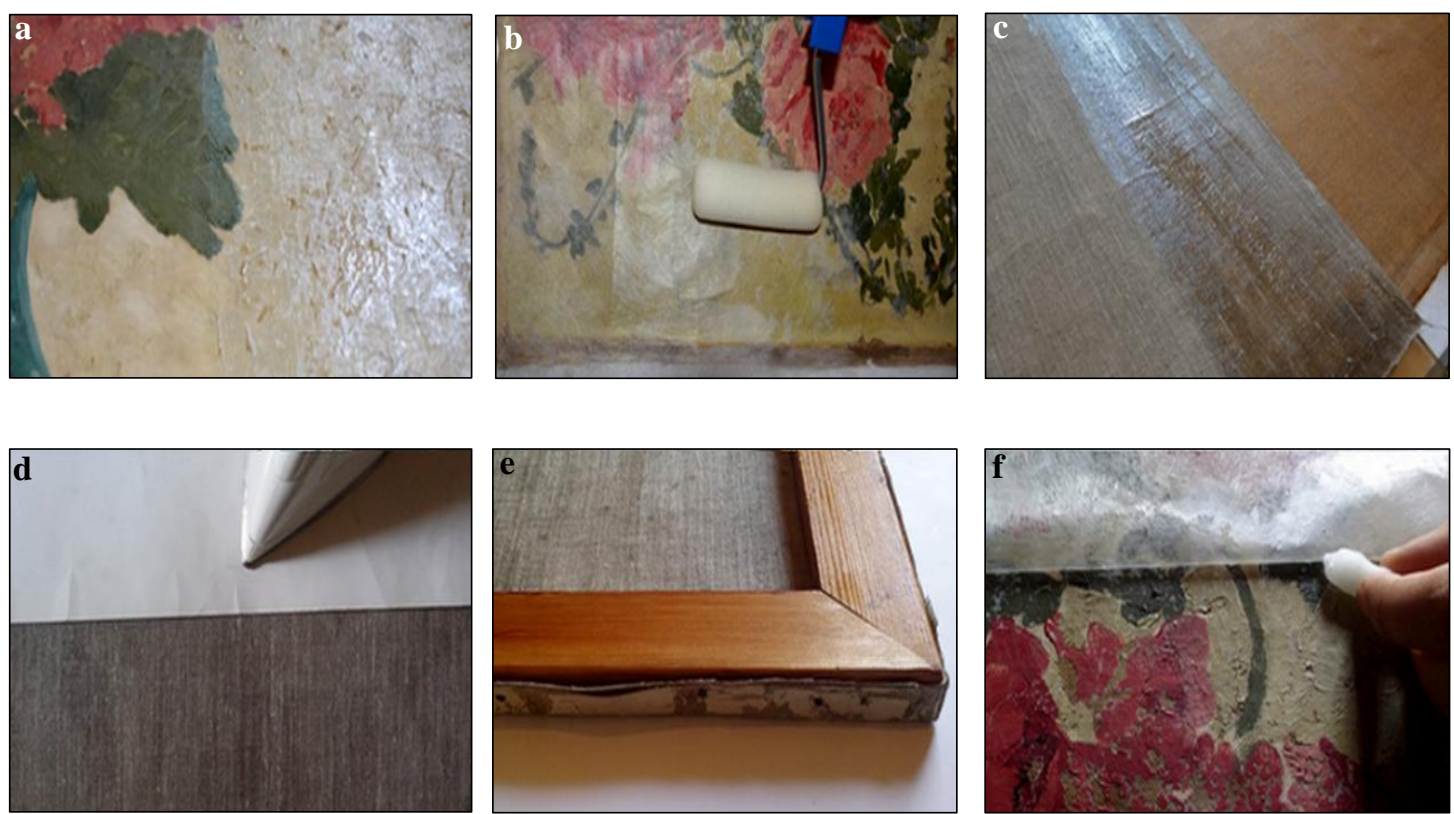

Figure (8) Shows lining steps, $\underline{\mathbf{a}}$. consolidation of paint surface, $\underline{\mathbf{b}}$. covering with tissue, $\underline{\mathbf{c}}$. coating the

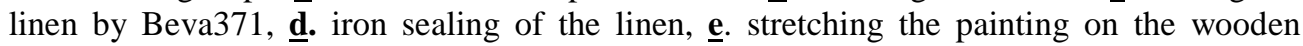
stretcher after treating it, f. removal of tissue and cleaning the residues

\subsection{Completion of the missing ground and paint areas}

According to the field observation and documentation of deterioration forms affecting our case, some missing parts in the canvas, the ground and the paint layers were noted. These parts were filled with the inserted linen pieces adhered with Beva371 before the full lining by the new linen textile support. In other parts, the painting and ground layers were jointly lost due to dust abrasion. In this case, a calcium carbonate paste mixed with animal glue was used to fill these

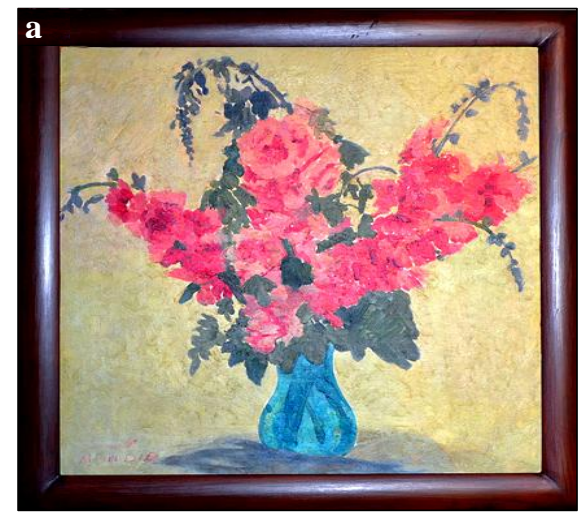

missing layers and left for 24 hours to dry. MAIMERI paint colors was used for inpainting the mis-sing colored parts. Furthermore, the Pebeo varnish was sprayed and left for three days to reach the full dry and stability as previously experimented by Stoner and Rushfield [9] and Pietro \& Ligterink [38]. Finally, the object was cleaned, retouched and varnished. The painting was fixed on the frame. Then, was prepared to be redisplayed at the Museum, fig. (9).

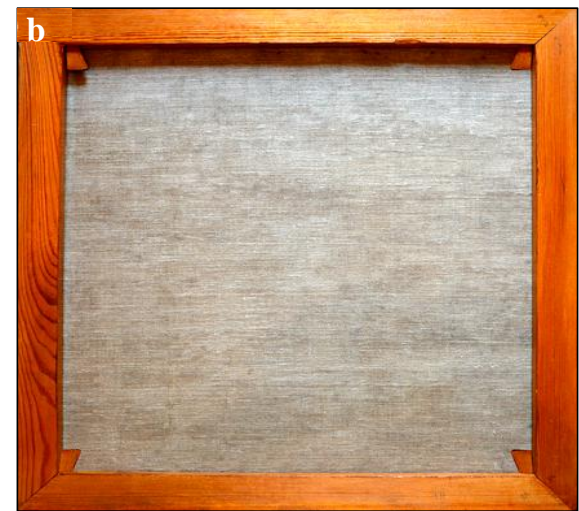

Figure (9) Shows the state of flowers painting (1) object $\underline{\mathbf{a}}$. face, $\underline{\mathbf{b}}$. verso after conservation process.

\section{Discussion}

The results of investigation and analyses showed that the object suffered from severe deterioration phenomena, including dust, stains, cracks, macro-cracks, ruptures, holes, missing parts in the painting and the ground layers. In addition, fragility, brittleness and ancient incorrect treatments. They can be attributed to 
main four deterioration factors and related mechanisms. They are three external and the fourth is internal. The $1^{\text {st }}$ one is fluctuations in temperature and humidity due to the lack of environmental systems' control. The $2^{\text {nd }}$ factor is dust and air pollutants due to the high level of pollution in Cairo and improper ventilation system. The $3^{\text {rd }}$ factor is attributed to the man-made damages including the incorrect ancient patching and inpainting. The $4^{\text {th }}$ one is the internal one related to the structure of the ground layer, paint layer, and canvas. The paint layer completely differs from the ground layer and canvas, as well. These differences usually lead to varying in the ratio of extension and shrinkage of all mentioned components. Furthermore, these variants showed cracks, macro-cracks, cleavage, flaking, separation of layer and the missing parts in both the paint and ground layers as argued by Stoner \& Rushfield [9], Stulik, et al. [32], Costa, et al. [39], in similar cases. Moreover, the painter utilized two, three or four pigments to produce one color hue caused many variations in shrinkage and extension ratios among the different pigments. It is well known that more mixed pigments lead to more cracks, macrocracks, cleavages, fragility and falling down of different layers $[4,40]$ as noted in fig s. $(1 \& 2)$. In the same context, other forms of brittleness and fragility could be created due to the absence of varnish layer, as reported by Karpowic [40] and Costa, et al. [41]. Through analyzing EDX results, it could be claimed that the presence of $\mathrm{Pb}$ in all samples is attributed to the white lead pigment used to give the paint the light tone [25]. XRD results revealed the presence of the white lead pigment (cerussite or hydrocerussite) in some samples, barite and zincite in others and both of them in some other samples. These variations can be interpreted that the white lead refers to the white ground layer, while, barite and zincite have been used as a lightening pigment to the paint. This result is supported by the presence of $89.7 \%$ hydrocerussite, $9.2 \%$ cerussite and $1.1 \%$ Zincite in the ground layer. XRD result of the gray sample revealed that there are green and white pigments only with no black ones. It confirms that the black pigment is carbon and it hasn't been discovered due to its organic origin. These results ensure that both EDX and XRD should be used to get detailed information about the main components of all sections of the canvas. Finally, the experimental section asserted that Beva371 is more suitable than the fish glue in the conservation of our samples, as a consoledat material. The, fish glue was not aceptable as a consolidant especially with using organic solvents-based materials [4,39].

\section{Conclusion}

The study is a supplementary one based on the recommendation of one of my previous related articles that focused on the analysis of five canvas paintings (including our present case study) at the Egyptian Agricultural Museum. The present study revealed that The Flowers Painting (1) can be artistically and historically dated back to 1937-1941. Through documentation and investigation processes using different techniques, the layer structure of the object revealed the absence of varnish, and the presence of different types of deterioration phenomena. Our object was mechanically and chemically cleaned, then consolidated using 7\% Beva371 in toluene due to its optimum results. The missing parts in the ground layer were filled up with calcium carbonate in animal glue. They were inpainted using Maimeri oil paint tubes, then sprayed using Pebeo varnish. Finally, the frame was treated and fixed upon the object, later it was re-displayed. In this regard, some recommendations should be taken into our account 1) installation of a central air condition system to control an maintain a suitable museum environment. 2) using suitable light sources for museum organic objects, such as fluorescent lamps and metal-halide lambs with filters absorbing ultraviolet radiations. 3) Using a dark background in the exhibition halls to absorb the light falling on it and not to reflect it upon the objects. 4) Establishing a conservation lab at the Egyptian Agricultural Museum provided with basic materials and tools of object treatment and employing some conservators to carry out these duties. 


\section{Acknowledgment}

The author would like to thank the Heritage Collections team at the Egyptian Agricultural Museum in Giza, Egypt for their support to carry out the activities related to the case study object.

\section{Endnote}

(a) An Egyptian famous painter (1909-1997), participated in the arts movement in Egypt, he was appointed as painter in the EAM in 1934, then, a director of that museum.

\section{References}

[1] Ackroyd, P. \& Villers, C., (2003). Increasing minimalism, in: Bustin, M., \& Caley, T., (eds.) Alternatives to lining: The structural treatment of paintings on canvas without lining, UK Institute for Conservation, London, pp: 9-14.

[2] Strlič, M. \& kolar, J., (2005). Ageing and stabilisation of paper, National and Univ. Library, Ljubljana, Slovenia.

[3] Thomson, G., (1985). The museums environment, $2^{\text {nd }}$ ed., IIC, London.

[4] Knut, N., (1999). The restoration of paintings, Koln, Könemann; Princes Risborough, translated by Cambridge, UK.

[5] Pietro, G. \& Ligterink, F., (1999). Prediction of relative humidity response of backboard-protected canvas painting, Studies in Conservation, Vol. 44 (4), pp: 269-277.

[6] Seves, A., Sora, S., Scicolone, G., Testa, G., Bonfatti, A., Rossi, E. \& Seves A., (2000). Effect of thermal accelerated ageing on the properties of model canvas paintings, J. of Cultural Heritage, Vol. 1 (3), pp: 315-322.

[7] Saunders, D., (2000). Pollution and the national gallery, in: Davies, D., (ed.) National Gallery Technical Bulletin, Vol. 21, pp: 77-91.

[8] Seves, A., Sora, S., Nocerino, S., Testa, G., Rossi, E. \& Seves, A., (1998). Kinetics of biodegradation of cellulose materials, Cellulose Chemistry and Technology, Vol. 32 (3), pp: 197-209.

[9] van Loon, A., Noble, P., \& Burnstock, A., (2012). Ageing and deterioration of traditional oil and tempera paints, in: Stoner, J. \& Rushfield, R., (eds.) The conservation of easel paintings, Routledge, pp. 214-241.

[10] Vallance, S., (1997). Critical review: Applications of chromatography in art conservation: Techniques used for the analysis and identification of proteinaceous and gum binding media, Analyst, Vol. 122 (6), pp: 75-81.

[11] Madariaga, J., (2015). Analytical chemistry in the field of cultural heritage, Analytical Methods, Vol. 7 (12), pp: 4848-4876.

[12] Doménech-Carbó, M. \& Osete-Cortina, L., (2016). Another beauty of analytical chemistry: Chemical analysis of inorganic pigments of art and archaeological objects, ChemTexts, Vol. 2 (14), pp: 1-50.

[13] Calvano, C., van der Werf, I., Palmisano, F. \& Sabbatini, L., (2016). Revealing the composition of organic materials in polychrome works of art: the role of mass spectrometry-based techniques, Analytical and Bioanalytical Chemistry, Vol. 408 (25), pp: 69576981.

[14] Stuart, B., (2007). Analytical techniques in materials conservation, $1^{\text {st }}$ ed., John Wiley \& Sons.

[15] Bonaduce, I., Ribechini, E., Modugno, F., Colombini, P., (2016). Analytical approaches based on gas chromatography mass spectrometry (GC-MS) to study organic materials in artworks and archaeological objects, in: Mazzeo, R., (ed.) Analytical Chemistry for Cultural Heritage, springer, pp: 291327. 
[16] Lee, J., Ormsby, B., Burnstock, A. \& van der Berg, K., (2017). The chemical characterisation of water sensitive modern oil paint swatches by Winsor \& Newton, in: Bridgland, J., (ed.) ICOM-CC $18^{\text {th }}$ Triennial Conference preprints, Copenhagen, ICOM-CC, 12 p.

[17] Bay, L., Lee, J., Ormsby, B., Burnstock, A. \& van der Berg, K., (2017). Water sensitivity of modern oil paintings, in: Bridgland, J., (ed.) ICOM-CC $18^{\text {th }}$ Triennial Conference preprints, Copenhagen, ICOM-CC, $10 \mathrm{p}$.

[18] Steyn, L., Stols-Witlox, M., Hendriks, E. \& van den Berg K., (2017). Cleaning modern oil paints: The removal of imbibed surface dirt: Towards an integrated conservation methodology for the assessment, contextualization and treatment of imbibed surface dirt on unvarnished modern oil paintings, in: Bridgland, J., (ed.) ICOM-CC $18^{\text {th }}$ Triennial Conference preprints, Copenhagen, ICOM-CC, 1 p.

[19] Iafrate, S., Andreano, M., Ioele, M., Jervis, A.., Paris, M., \& Santamaria, U. (2011). Research study on supporting materials and adhesives for the restoration of gilt leather: first results, in: Bridgland, J., (ed.) ICOM-CC $16^{\text {th }}$ Triennial Conference preprints, Lisbon, ICOM-CC, 9 p.

[20] Hartin, D., Hagan, E., \& Michalski, S., (2014). The CCI lining project final results: Extreme temperatures, extreme humidities, and complete master curves, in: Bridgland, J., (ed.) ICOM-CC $17^{\text {th }}$ Triennial Conference preprints, Melbourne, ICOM-CC, 1 p.

[21] Barten, J., Laganà A., \& van Oosten, T., (2017). Seen from behind: Consolidation of painted works on poly (methyl methacrylate) by László Moholy-Nagy, in: Bridgland, J., (ed.) ICOM-CC $18^{\text {th }}$ Triennial Conference preprints, Copenhagen, ICOM-CC, $8 \mathrm{p}$.
[22] Colombini, M., Modugno, F., Giacomelli, M. \& Francesconi, S., (1999). Characterisation of proteinaceous binders and drying oils in wall painting samples by gas chromatographymass spectrometry, J. of Chromatography A, Vol. 846 (1), pp: 113-124.

[23] White, R. \& Pilc, J., (1996). Analyses of Paint Media, in: Davies, D. \& Green, J., (eds.) National Gallery Technical Bulletin, Vol. 17, pp: 91-103

[24] Needles, H., (1986). Textile fibers, dyes, finishes, and processes, Noyes Publications, USA.

[25] Elsayed, Y., (2015). Identification of oil media in five canvas paintings at the Agricultural Museum in Egypt, J. of Faculty of Archaeology (Qena), Vol. 10, pp: 60-92

[26] Derrick, M., Stulik, D. \& Landry, J., (1999). Infrared Spectroscopy in Conservation Science, Scientific Tools for Conservation, Getty Conservation Institute, NY.

[27] Sarmiento, A., Perez-Alonso, M., Olivares, M, Castro, K., MartinezArkarazo, I., Fernandez, A. \& Madariaga, M., (2011). Classification and identification of organic binding media in artworks by means of Fourier transform infrared spectroscopy and principal component analysis, Analytical and Bioanalytical Chemistry, Vol. 399 (10), pp: 3601-3611.

[28] Sakr, A., Ghaly, M., Geight, E. \& Abdel-Haliem, M., (2016). Characterization of grounds, pigments, binding media, and varnish, coating of the Angel Michael' icon, $18^{\text {th }}$ century, Egypt, J. of Archaeological Science: Reports, Vol. 9, pp: 347-357.

[29] Pilc, J. \& White, R., (1995). The application of FTIR-Microscopy to the analysis of paint binders in easel paintings, in: Davies, D. \& Green, J., (eds.) National Gallery Technical Bulletin, Vol.16, pp: 73-84.

[30] Gruchow, F., Machill, S., Thiele, S., Herm, C., Salzer, R., (2009). Imaging FTIR Spectroscopic Investigation of Wood: Paint interface of Aged Polyc- 
hrome Art Objects, e-Preservations Science, Vol. 6, pp: 145-150.

[31] Munos-Vinas, S., (2005). Contemporary theory of conservation, Butterworth-Heinemann, Oxford.

[32] Stulik, D., Miller, D., Khanjian, H., Khandekar, N., Wolbers, R. \& Petersen, W., (2004). Solvent gels for the cleaning of works of art: The residue question, Getty Pub., Los Angles.

[33] Cruz, A. \& Rego, C., (2014). Scientific study of an $18^{\text {th }}$ century Portuguese painting on canvas and their old restoration: problems of date and authenticity of the current image, ICJS, Vol. 5 (4), pp: 479-492.

[34] Berger, G., (1975). Heat-seal lining of torn painting with Beva371, Studies in Conservation, Vol. 20 (3), pp: 126-151.

[35] Bianco, L., Avalle, M., Scattin, A., Croveri, P., Pagliero, C. \& Chiantore, O., (2015). A study on reversibility of BEVA ${ }^{\circledR} 371$ in the lining of paintings, J. of Cultural Heritage, Vol. 16 (4), pp: 479-485.

[36] Hackney, S., (2003). Reline, Line, Deline, in: Bustin, M. \& Caley, T., (eds.) Alternatives to lining: Structural treatment of paintings on canvas without lining, UK Institute for Conservation, London, pp: 5-8.
[37] Pietro, G. \& Ligterink, F., (1999). Prediction of relative humidity response of backboard-protected canvas painting, Studies in Conservation, Vol. 44 (4), pp: 269-277.

[38] Karpowic, A., (1990). A study on development of cracks on painting, $J$. of American Institute for Conservation, Vol. 29 (2), pp: 169-180.

[39] Costa, T., Ritcher, F., Correia, M., Escorteganha, M., Santiago, A., Gonçalves, S., Spudeit, D., Micke, G. \& Miranda, F., (2016). Multitechnical analysis as a tool to investigate structural species in the "replica" of First Mass in Brazil painting by Sebastião Vieira Fernandes, J. of Molecular Structure, Vol. 1120 (15), pp: 196-204.

[40] Debnath, N. \& Vaidya, S., (2006). Application of $\mathrm{x}$-ray diffraction technique for characterization of pigments and control of paints quality, Progress in Organic Coatings, Vol. 56 (2-3), pp: 159-168.

[41] Soppa, K., Laaser, T., Krekel, C., Genton, M. \& Seidel, T., (2014). Adhesion and penetration of sturgeon glue and gelatins with different Bloom grades, in: Bridgland, J., (ed.) ICOMCC $17^{\text {th }}$ Triennial Conference preprints, Melbourne, ICOM-CC, 9 p. 